Nadhira Aprilia Supriyadi ${ }^{1}$, Moses Glorino Rumambo Pandin ${ }^{2}$

${ }^{1}$ Faculty of Psychology, ${ }^{2}$ Faculty of Humanities

Airlangga University

Jl. Airlangga No.4-6, Airlangga, Kec. Gubeng, City of Surabaya, East Java 60115

Email: nadhira.aprilia.supriyadi-2020@psikologi.unair.ac.id, moses.glorino@fib.unair.ac.id

\title{
BOOK REVIEW: GRAND STRATEGY TOWARDS A ONE CENTURY INDONESIA INDEPENDENCE IN 2045
}

Book title: Grand Strategy Towards an Indonesian Century in 2045; Authors: Atmadji Sumarkidjo and Ian Montratama; Publisher: Kata Hasta Pustaka Publisher; City of publication: Jakarta; ISBN: 978-9791056-72-4; Year of publication: 2020; Book Size: 22.5 x 15 cm; Pages Thickness: 465 Pages

To celebrate Indonesia's centenary in 2045, the Indonesian needs to prepare themselves from now on. By solving various problems currently and occurring and formulating strategies for Indonesia's progress in the future, it is hoped that it it can become a stepping stone to realizing the aspirations of the Indonesian nation. The book, entitled "Grand Strategy Towards One Century Indonesia in 2045" is intended to build awareness of the Indonesian so that they can maintain its existence amid all the opportunities and challenges that exist in the 21 st century.

The collaboration between policymakers and the future generation as actors who will play an essential role in the future is the main topic in this book. Therefore, it is addressed to the younger generation, who played an important role in determining Indonesia's fate in the future. The audience or readers of it tend to be aimed at an educated group.

"Grand Strategy Towards One Century Indonesia in 2045" is a book that describes the major problems faced by the Indonesian nation and the solutions to solve these problems in the recent era. All these efforts are carried out to celebrate the hundred years of Indonesian independence. Then there is an analysis in formulating strategies and overcoming the problems that occur, Pancasila is needed as a carrier to underlie every action that will be taken. The neverending corruption, separatist movements, disintegration of the nation, and other problems can be solved by implementing Pancasila in the life of society and the state.

On this basis, it is important to review it in order to broaden the readers' horizons and cab think to more critically and visionary. It is also important to read by the Indonesian people, especially regulators and the younger generation, so they can know what things should be done to realizing a golden Indonesia in 2045. Finally, understanding this kind of book is deemed necessary to create Indonesian people who uphold the values of Pancasila in a community and state life.

Indonesia as a modern country that relatively young has been able to survive the 20th century safely, despite several political and monetary crises. In this 21 st century, the Indonesian nation remains determined to continue to carry out reforms in all fields. Therefore, the book entitled "Grand Strategy Towards One Century Indonesia in 2045" is intended to build awareness of the Indonesian so that it can maintain its existence amid all the opportunities and challenges that exist in the 21 st century. Indonesia, which is currently faced various problems such as the middle-income trap, the post-pandemic recovery process, the nation's disintegration, to rowing the geopolitical ocean in an international political cycle, must be able to overcomit these problems in order to maintain its dignity as a great nation. However, despite the various problems that have occurred, the younger generation is becoming a growing figure and will become the skipper or control holder of Indonesia in the 100th year of independence in 2045 .

In this book, it is conveyed that the younger generation still has many opportunities to always maintain the integrity and are never afraid to dream. This determination is needed to achieve the vision of a developed Indonesia that is sovereign, independent, and has a personality so that it becomes a great country that will be present in the future. This spirit must of course be accompanied by instilling Pancasila values as the identity of the Indonesian nation as well as guiding principles to achieve the ideals dreamed by the nation's founders. Therefore, this book is intended for all Indonesian people, especially leaders who are in control today to be able to 
realize Indonesia's progress in the future. Also of course for the younger generation as a figure who will take control of this nation in the future.

This book can meet the needs of readers in finding information about visionary views and actions that must be taken in realizing a golden Indonesia in 2045. One of the contents of the book that displays this information is a discussion of the new challenges facing Indonesia, namely improving the quality of the younger generation to become qualified human resources. This challenge occurs as a result of differences in education levels in Java and outside Java, a homework that has been going on for decades. Education ranging from elementary to high school in the regions, the quality is still lagging behind the big cities in Java. If analyzed in more depth, this problem turns out to be caused by the quality and distribution of the teaching staff who are still experiencing various obstacles.

The success and failure of a country depend on its human resources. The road to success in achieving Indonesia's vision of becoming a developed country in 2045, therefore, depends very much on how capable the Indonesian nation is to produce quality human resources. All human resources in various sectors must be developed by their specialties. However, this increase will not be possible if the educational problems previously described continuing and are not taken seriously. Education is the first step in building the quality of human resources for the better. Improving the quality of teachers, improving educational facilities and infrastructure, and developing research must be continuously improved to ensure that the educational process can run smoothly. In addition, mental and character education also needs to be pursued through formal education. The existing education system must be able to adopt behavioral education through scientific methods by educational psychology.

"Grand Strategy Towards One Century Indonesia in 2045" is a book that explains various new things, such as at least seven tough challenges for the Indonesian nation in entering this millennial era. First, is the implementation of the noble values of Pancasila which feel 'majestic'. Second, is the implementation of democracy in Indonesia which seems to be increasingly 'heretical'. Third, is the expansion of the economic neoliberalism movement. Fourth, is the issue of the caliphate and communism which increasingly threatens unity. Fifth, is the development of IT (Information Technology) which is increasingly widespread, besides being useful, it has many disadvantages. Sixth, about the never-ending eradication of separatism. Seventh, there are legal issues and corruption that still occur as if there is no reflection.

However, the toughest challenge in building the young generation of the Indonesian nation in the future is implementing the values of Pancasila which are blunt and doubtful for the younger generation. Pancasila can be said to be blunt because, during this era of reformation, new methods have not been found that are appropriate to provide education, teaching, appreciation, and the practice of Pancasila that can be felt by the community. As a result of hatred towards the New Order, almost everything related to government policies was abolished in the reform era since 1999, including the P4 program. This resulted in almost the first ten years of the reform era, there was not yet the right organization for the socialization and implementation of Pancasila to the public. This is the location of the majesty of the Pancasila education system today. Although currently, the government has formed the Pancasila Ideology Advisory Board (BPIP), it seems that the issue of Pancasila has not yet ended, and there are often various debates.

It also stated that some new evidence is also presented regarding the values of Pancasila which are becoming increasingly biased in society. In the book, it is explained that Pancasila today and in the future will experience a degradation of understanding if the situation of the Indonesian nation continues like this. Advances in technology, for example, actually make people seem 'mute' and become more individualistic, causing the values that exist in Pancasila to be increasingly eroded in its implementation. Pancasila calls for social cohesion, mutual tolerance, and help. As the identity of the Indonesian nation, Pancasila should be able to be implemented in the life of the Indonesian people as a nation and state. Apart from that, the rampant corruption, widespread neoliberalism movement, national disintegration, and separatist movement strengthens the evidence that Pancasila is facing erosion and practice.

Evidence of the increasing erosion of Pancasila is also strengthened through the data presented in the book. For example, the existence of the Armed Criminal Group (KKB) in Papua 
which is still operating against Indonesia at this time shows that Pancasila has not been fully lived up to by the Indonesian people (p. 69). Then data on corruption in Indonesia, for example, in 2018 Indonesia Corruption Watch (ICW) recorded 454 corruption cases with total state losses reaching more than 5 trillion rupiah in just one year. According to Prof. Emil Salim, that more than $80 \%$ of the perpetrators of corruption are public officials and even the political elite. (p. 78). Such phenomena clearly illustrate that Pancasila cannot be fully implemented by the Indonesian nation, even by those in power who should be role models for society. Therefore, if these conditions cannot be repaired, what will happen will only be the erosion of the daily appreciation and practice of Pancasila.

After examining this book, various challenges and obstacles to the future will be found to continue national development towards advancing Indonesia in 2045. Therefore, strategic policies are needed to be able to answer these challenges and at the same time find wise solutions to realize the vision for the future. It presents solutions and actions in the form of strategies that must be carried out in dealing with various problems that occur. The young generation and deep understanding of the values of Pancasila are the main keys in the grand design to realize the strategy to achieve progress towards a century of Indonesia in 2045.

This book has a quite interesting style, by displaying large writing on the cover and only displaying a picture of a mountain peak with a sky blue background. The first impression that is displayed is quite interesting because the combination of the title looks visionary and the image of the sky and mountains gives a sublime symbol. The content of this book is quite difficult for the public to understand because it often uses several terms that are rarely used. Because this is a book written scientifically, the audience or readers of it tend to be among the educated and more specifically among academics. The contents of it are opened by discussing the prediction of challenges that will be faced by the Indonesian nation in the future. Then in the next section, we will discuss matters surrounding the development and development of Indonesia's human resources. In the final section, the discussion will focus on the involvement of the young generation and the role of Pancasila as the key to building Indonesia in the future, and how strategies must be prepared to achieve a golden Indonesia on the 100th anniversary of independence later. This book has a fairly heavy mass because it is 2.5 centimeters thick and has 465 pages in it. The size of it can be said to be quite large with a size of $22.5 \times 15 \mathrm{~cm}$. It can be categorized as general books that discuss scientific topics which have a large enough thickness with this characteristics.

The writings in this book tend to lead to visionary thoughts followed by various concepts and data research that support these thoughts. Unfortunately, in the writings that discuss things related to Pancasila, the author of it does not present historical events and thoughts of national figures as the foundations for Pancasila. The writings on Pancasila in it tend to focus only on its implementation and enrichment but have not been studied in depth. This is important considering that by understanding historical events that exist the readers will be able to absorb the meanings or essence contained in Pancasila. Then by exploring the thoughts of the founding fathers as the founders of Pancasila, readers will be able to understand the concept of Pancasila in a philosophical way.

In addition, other suggestions that can be given to book authors are to include data that is more significant and credible. Even though the data presented can be said to be reliable and relevant, if we look at it more broadly, other data can support the content of the writing to be good, such as research conducted by international institutions. Meanwhile, the theories and thoughts presented in this book have been written very well, through quotes from various great figures in the national and international spheres. Because it is structured through a scientific frame of mind and is presented in a fairly high level of language, this has become an obstacle for some readers to understand its content. Apart from this, the content in it can broaden horizons and help readers to think more critically and visionary. Therefore, the book entitled "Grand Strategy Towards One Century Indonesia in 2045" is important to read to build awareness of the Indonesian nation in maintaining its existence amid all the opportunities and challenges that must be faced. 


\section{References}

Sumarkidjo, Atmadji and Montratama, Ian. (2020). Grand Strategy Towards One Century Indonesia in 2045. Jakarta: Said Hasta Pustaka

\section{Authors:}

Armadji Sumarkidjo is a journalist who started his career as a reporter in 1979 at the Harian Umum Sinar Harapan ( $\mathrm{SH}$ ) and later became an editor in the field of Defense and Security at SH then moved to electronic media, and became Deputy Editor in Chief of Rajawali Citra Televisi Indonesia (RCT1) until 2009. Born in Jakarta, he completed his education at the Publicity College (STP, now called IISIP) in Jakarta and then received his Masters degree from the Technological University of the Philippines, Manila, Philippines. Previously he was awarded a Fullbright Fellow at the Center for Foreign Journalist (CFJ) in Reston, Virginia, USA. While carrying out his function as a journalist, the author since 1997-2013 has been a lecturer at the Faculty of Communication Sciences, Mercu Buana University (UMB) and a lecturer at the UMB Postgraduate Program.

In 2015, he entered the government and became the Special Staff of the Indonesian Presidential Chief of Staff (2015), Special Staff of the Coordinating Minister for Political, Legal and Security Affairs of the Republic of Indonesia (2015-2016), Special Staff of the Indonesian Coordinating Minister for Maritime Affairs (2016-2020).

Self-written books: Mendung di Atas Istana Merdeka (2000), Jenderal M. Jusuf, Panglima Para Prajurit (2006). TB Simatupang Bercerita Tentang Pengalamannya (2008). Mission Accomplished, Operasi Kapal Selam RI Tjandrasa (2010), 25 Tahun Universitas Mercu Buana (2011), Anak "Jenderal Bola": Menjalin Persaudaraan dengan Sepakbola (2013), The Admiral Lakda TIMI Sudibyo Rahardjo (2013), Surjadi Soedirdja: Pengabdian Tanpa Henti (2016)

lan Montratama is a lecturer in international relations at Pertamina University. His background knowledge is from economics from the University of Indonesia (S1), business from EDHEC Lille (S2), universal war strategy from the University of Defense (S2), and international relations (S3). Apart from teaching, he also enjoys writing and researching. More than eight of his books have been published. Apart from that, he is also a sales consultant for the defense industry. The books he has written include, Indonesia Inc.: Peta Jalan Menuju Poros Maritim Dunia (2019), Terorisme Kanan Indonesia: Dinamika dan Penanggulangannya (2018, together with Obsatar Sinaga \& Prayitmo Ramelan), Quo Vadis Politik Luar Negeri Indonesia (2017, with Yanyan Mochamad Yani), and Arungi Samudra Bersama Sang Naga: Sinergi Poros Maritim Dunia dan Jalur Sutra Maritim Abad Ke-21 (with Untung Suropati and Yohanes Sulaiman, 2016) 